\title{
THE CHANGING NATURE OF EARLY CHILDHOOD CARE AND EDUCATION IN IRELAND
}

\author{
Gemma Kiernan and Thomas Walsh
}

\section{Abstract}

This paper traces the evolution of early childhood care and education (ECCE) in Ireland over the course of the last century. Changing conceptualisations of the nature of childhood provide the context for understanding historical and contemporary approaches to ECCE. Historically, young children's care and education were treated as separate entities, with 'care' provided within the home and 'education' outside the home. However, the contemporary perspective recognises that young children's learning occurs on a continuum from birth, with care and education being interdependent. Although a distinct ECCE sector is beginning to emerge, prompted by developments at policy, practice and research level, there is considerable scope for further progress. Given 'where we have come from' and 'where we are currently at', future directions and recommendations for ECCE are elucidated.

\section{Introduction}

Early childhood care and education (ECCE) has changed, and indeed is currently in a state of change, in Ireland. Demographic, economic and socio-cultural developments, and more notably, transformations in our conceptualisation of childhood, provide a backdrop for understanding this. Whereas historically care and education were largely treated as separate entities, contemporary perspectives recognise them as interrelated and interdependent. This is catalysing the emergence of a distinct ECCE sector, which has stimulated developments at policy, practice and research level. At this point, it is an opportune time to consider how to best progress ECCE in the Irish context into the future.

The first part of this paper focuses on the historical period from 1900 to 1990, elucidating perceptions of childhood and 
examining the main characteristics of early childhood care and early childhood education. Secondly, the contemporary context from 1990 to the present day is examined, relating transformations in our perceptions of childhood to the emergence of a distinct ECCE sector, which recognises that young children's care and education are inextricably linked. The final part of this paper draws on the preceding historical and contemporary analysis to present a vision for ECCE in Ireland. Specifically, future directions for the sector are identified and recommendations are made regarding the structures and resources that need to be put in place to ensure progress.

\section{Part 1: The historical perspective \\ Conceptualisation of childhood 1900-1990}

Our concept of children is context-linked and time-specific (Cleary et al., 2001; Smyth, 2003) and has evolved greatly over the past hundred years. Clancy (1984) notes that, in the early part of the century, families were invariably large with a modal size of seven to nine children in 1911, reducing to four to six children in the 1970s. Curtin (1986) argues that this was to ensure generational continuity, as a source of labour and to ensure assistance into old age for parents. Infant mortality was particularly high in the early decades of the twentieth century, running at nearly ten percent in 1910 (Kennedy, 1989).

Hannan and Katsiaouni (1977) and Fahey and McLaughlin (1999) hold that there is a dearth of documented research for much of the twentieth century outlining the position of children within the family and society. Certain anthropological studies and biographies provide insights into the place of children within the home. Arensberg and Kimball (1940) observed homes in Clare in which the child was the centre of the family, cared for primarily by the mother and extended family, such as grandparents, aunts and siblings, and, to a lesser extent, in the early years by the father. Scheper-Hughes (1979) notes that fathers played a more prominent role in the later years in the socialisation of males, usually after the child had celebrated his First Holy Communion. In tandem, mothers prepared the female children for their future roles within the home. There is some evidence that male children were preferred to girls owing to the fact that they would continue the family name (Scheper-Hughes, 1979; Curtin and Varley, 1984). 
A number of commentators, including Scheper-Hughes (1979), Curtin and Varley (1984) and Kerrigan (1998), hold the view that, in the early part of the twentieth century, children did not assume a prominent position in Irish society. They provide an image of children as being shy and withdrawn, speaking only when spoken to. As Arensberg and Kimball $(1968$, p. 38$)$ stated, 'They are very silent children. They take little part in the family discussion between older members unless questioned directly'.

There is some evidence (Scheper-Hughes, 1979) that young children up to the 1970s were largely kept indoors, protected away from the community and that, upon reaching school-going age, they became more visible and prominent in the community. Children born with disabilities were often cared for by their families or within institutions and there is evidence that some children with disabilities were hidden away from society (Scheper-Hughes, 1979). The Committee on Reformatory and Industrial Schools (1970) and O'Sullivan and Raftery (1999) provide much evidence of the harsh treatment of some children cared for within reformatory and industrial schools.

The methods of disciplining children have evolved greatly in the course of the twentieth century. Corporal punishment was a common feature both within the home and school settings throughout much of the century, with its abolition within the education system occurring in 1982 (Coolahan, 1981). Commentators remark that corporal punishment was utilised within a Catholic doctrine framework, to combat the weaknesses imposed by original sin, even in the early years (Scheper-Hughes, 1979).

A number of policies and pieces of legislation both impacted on and reflected our conceptualisation of children in the twentieth century. The Children's Act (1908) was a landmark document for the care of children in Ireland. This focused on the treatment as opposed to the punishment of children and bestowed upon children a separate legal status. This Act was replaced by the Child Care Act (Department of Health, 1991). The United Nations Declaration on the Rights of the Child (1959), the UN International Year of the Child in 1979 and UN Convention on the Rights of the Child in 1989 (UN, 1989) (ratified by Ireland in 1992) raised the profile and prominence of children as citizens in society. 


\section{Analysis}

This overview suggests that a number of key elements characterised the conceptualisation of childhood in the twentieth century. Firstly, children were largely 'cared' for within their families, primarily by their mother, while fathers and extended families played a less significant role. Secondly, there was an emphasis on discipline and the strict control of children, emanating from the doctrine of original sin. Thirdly, in society, young children were not a prominent cohort of citizens and their lack of visibility impacted negatively on the provision of services for this age group.

\section{Early childhood care 1900-1990}

For the greater part of the twentieth century, the vast majority of children in Ireland were cared for within their own homes, primarily by their mothers. Arensberg and Kimball (1940) paint a positive image of the care afforded to the child within the home and the centrality of children within the family.

In the earlier part of the twentieth century, commentators such as Curtin et al. (1984) and Curtin (1986) note that many households contained three generations, incorporating grandparents or grandaunts, parents and children. Arensberg and Kimball (1968) suggested that this model provided assistance for mothers in rearing children, as this was often combined with multiple duties both inside and outside the home. The decline in the prevalence of the three generational family impacted on the availability of personnel to aid child rearing and childcare within the home and many commentators remarked the impact of this on the childcare process. Scheper Hughes (1979) argues that this placed the mother's time under greater pressure and that children lost their centrality within the home, often placed in a cot or crib and not always present with the rest of the family.

The involvement of fathers in child rearing, especially for young children, remained low throughout much of the century as was evidenced by many biographies and anthropological studies. Arensberg and Kimball (1940) characterise the father as distant and authoritarian. A change is noted in studies by Humphrey (1966), Peskett and Roberts (1972) and Hannan and Katsaiouni (1977), whereby fathers played a far greater role in the lives of young children in the urban context. However, later in the century, commentators such as Scheper-Hughes among others revealed that the participation 
of fathers in child rearing remained low: 'The role of the father in early child-rearing, however, is quite minimal. Until the age of four or five, children are very much the property and concern of their mothers' (1979, p. 148).

The demographic, economic and social changes in the latter part of the twentieth century catalysed an evolution of the ways in which children were cared for in Ireland. Increasing numbers of mothers entered the workforce and with increased urbanisation, there were reduced family and community supports to assist the childcare process. In the absence of state provision, movements began from the late 1960s to provide such services on a community or private basis (Douglas, 1994). Such services have included childminding, nurseries, Montessori schools, community playgroups, grúpaí naíonraí and preschools.

\section{Early childhood education 1900-1990}

The period of full-time care within the home ended usually when the child began formal education in the infant classes of the primary school, typically between the ages of three and six years. There were three major curricular reforms that impacted upon the infant classes between 1900 and 1990. The Revised Programme of 1900 (Commissioners of National Education, 1901) was a radical departure from the narrow and literary curriculum in operation previously under the system of Payment by Results. It introduced an array of subjects including Educational Handwork, Drawing, Elementary Science, Singing, Physical Drill, Cookery and Laundry. There was a greater emphasis placed on the infant classes with the introduction of Kindergarten principles and methods, while schooling was to be an enjoyable and discovery-oriented experience. Subjects were to be taught in a heuristic and integrated fashion with an equal emphasis on literary and practical subjects. Junior Assistant Mistresses were employed in schools under a male teacher to provide appropriate instruction for the infant classes (Starkie, 1911). Commentators such as Coolahan (1973) and Hyland (1987) noted problems with the implementation of such a radically different curriculum, exacerbated by poor financing, alienation of the educational stakeholders and a lack of understanding of the philosophies underlying the programme.

The Irish government began a process of curricular reform prior to independence to frame a curriculum appropriate to Irish sensibilities and ideology, in an attempt to afford to Irish children the 
cultural inheritance that had been denied to previous generations. The result was a narrower programme, focusing on the core subjects, with a particular emphasis on the Irish language and culture (National Programme Conference, 1922). The infant classes occupied a specific role within this drive for the revival of the Irish language, with all subjects being taught through the medium of Irish in these classes. As O'Connor states, 'Infants were no longer to be looked upon as the passive 'babies' of the early nineteenth century. They came to the fore as the leaders of the language revival movement in Ireland' (1987, p. $5)$.

This policy affected all infant classes, ninety per cent of which spoke no Irish in the home (Fox, 1978), and despite a relaxation of this policy from 1926 to 1934 allowing some English to be used, it remained in operation until 1960. Following calls for reform in the 1930 s and 1940s, a revision of the infant class programme was introduced in 1948, which employed many of the underlying philosophies of the Revised Programme of 1900 (Department of Education, 1948).

Economic and social developments in the 1960 s led to increased awareness of the need for reform within the primary school curriculum. The result was the New Curriculum (Department of Education, 1971), which was child-centred and heuristic. This was once again a radical change from its predecessor. The curriculum sought to inculcate greater independence and self-reliance while a great emphasis was placed on creating a disposition for learning as well as transmitting actual content. Hyland (1987) argues that the lack of ownership on the part of teachers and other obstacles impeded the implementation of the provisions. The Report of the Review Body on the Primary Curriculum made a number of recommendations regarding the Primary School Curriculum, including the revision of the content of many of its subjects and the resources needed for its full implementation (Department of Education, 1990).

\section{Part 2: The contemporary perspective}

Conceptualisation of childhood $1990-2004$

The 1990s to the present day have witnessed marked changes in society's perceptions and understanding of childhood. Greene and Moane's (2000) analysis of children's lives in Ireland conveys that a high level of flexibility and adaptability is expected from children today. They point out that children live in smaller, increasingly 
diverse family structures. The average number of children per family decreased from 2.2 in 1981 to 1.6 in 2002 (Central Statistics Office, 2002). Greene and Moane (2000) highlight that, in the wake of the Celtic Tiger, the greater participation of mothers in the workforce has led to an unprecedented demand for early childhood services, meaning that many young children today are exposed to the care and early education practices of adults other than their family.

There is an emerging consciousness regarding children's rights and a move toward a more State-interventionist approach in children's lives. Ireland's ratification of the UN Convention of the Rights of the Child (UN, 1989) in 1992 was an important milestone in this regard. It is based on a view of children as active participants in their own lives with civil, economic, social and cultural rights that are distinct from adults and it makes a clear statement regarding the State's role in providing assistance to parents in their childcare responsibilities. The National Children's Strategy (Department of Health and Children [DHC], 2000) marked a further shift in the development of a rightsbased approach to children, emphasising the goals of giving children a voice in matters which affect them, of ensuring children receive quality supports and services and of achieving a better understanding of children's lives.

There has also been an increasing concern for children's welfare and again, there is evidence of a more interventionist approach on the part of the State. This has perhaps been prompted by the disclosure of the neglect and abuse of many children in families and religious-run institutions in previous decades (Lalor; 2000) and by the fact that Ireland has one of the highest rates of child poverty in the EU (Harvey, 2001). The introduction of legislation such as the Child Care Act (Department of Health, 1991) and the Children Act (Department of Justice, Equality and Law Reform [DJELR], 2001) represent significant developments in an overall approach to protecting and supporting children's welfare. In addition, the launch of the National Anti-Poverty Strategy (Department of Social Welfare, 1996) and the publication of National Guidelines for the Protection and Welfare of Children (DHC, 1999) represent further measures in this regard.

There is growing recognition of the importance of the early years in children's lives and of the benefits of quality ECCE. Neuroscience and psychological research has demonstrated that a high percentage of children's learning takes place in the first six years of life (Shonkoff and Meisels, 2000). In light of this, quality ECCE is 
key to realising children developmental capacity. In a review of research in this area, Sylva (2002) found that high quality ECCE leads to lasting benefits in all areas of development, including the physical, cognitive, linguistic and social domains. Numerous commentators, such as Guralnik (1997), Currie (2000) and Holahan and Costenbader (2000), argue that quality ECCE is particularly important for children from disadvantaged backgrounds and children with special needs. There is evidence that quality ECCE is not only beneficial for the child and as a foundation for lifelong learning, but also for parents and families and for communities and wider society (Warfield, 1994; Guralnik, 1997; Barnett, 2000).

There is an increasing emphasis by policy makers, practitioners, including parents, and researchers on children's holistic development and learning. The Report of the Commission on the Family (Department of Social, Community and Family Affairs, 1998), for example, highlights that traditionally parents in Ireland tended to concentrate more on the physical well-being of their children, whereas now they are increasingly focusing on the holistic development of their children. This focus is reflected in the National Children's Strategy (DHC, 2000), which maintains that all the different dimensions of childhood development and learning must be addressed if children are to enjoy their childhood and make a successful transition to adulthood. The holistic perspective has highlighted that it is artificial to divide care and education in young children's lives; the interconnectedness of development and learning means that care and education must be interdependent and complementary.

\section{Analysis}

We have entered an era where children have an enhanced profile within public consciousness and on the national agenda. First of all, there is a greater respect for children's rights and needs. Additionally, there is a growing awareness of the importance of childhood, particularly the importance of early childhood as a formative time, with implications for lifelong development and learning. Furthermore, there is recognition of the importance of adopting a holistic approach to children's development and learning.

However, while there is a more obvious commitment to being child-centred, the reality is that there is still much to do if children in Irish society are to be valued and recognized as a discrete social group. Many aspects of the socio-economic context are not child 
friendly. For example, the organisation of family life around increased parental work demands, the inadequate standards of living and poverty that many children endure and the inadequate resources to support children who are disadvantaged and children with special needs impact negatively in this regard.

\section{Early childhood care and education}

The developments in our conceptualisation of childhood have stimulated a reconsideration of our approach to young children's care and education. Most notably, they highlight the inadequacies inherent in a separate childcare and education sector. In so doing, they are catalysing the emergence of a distinct ECCE sector, one that recognises children's needs and right to high quality provision, that bridges the gap between care and education and that focuses on young children's holistic learning and development (from birth to six years of age) in a variety of settings - families, playgroups, pre-schools, drop-in centres, childminders, crèches and nurseries, infant classes and after-school groups. The identity of this sector is being shaped by developments at policy, practice and research level.

\section{Policy}

At policy level, there are two key indigenous initiatives relevant to ECCE. The National Childcare Strategy (DJELR, 1999) highlights the needs and rights of children whose parents are active in the labour market. It makes a clear and unambiguous statement that 'care and education are inextricably linked elements in a child's holistic development' (DJELR, 1999, p. 45). The National Co-ordinating Childcare Committee and thirty-three City and County Childcare Committees were established to realise the Strategy's recommendations at national and local level respectively. The Equal Opportunities Childcare Programme (EOCP) is the primary source of current funding with a budget of $€ 449$ million to be spent between 2000 and 2006 on expanding provision and access to early childhood services, supporting the staffing and enhancing the quality of these services.

The White Paper Ready to Learn (Department of Education and Science [DES], 1999a) aims to support the development of children through high quality early education with a particular focus on the target groups of the disadvantaged and those with special needs. It highlights that '.. for young children, education and care 
should not be separated, but should be provided in a complementary seamless fashion' (DES, 1999a, p. 4). The Centre for Early Childhood Development and Education (CECDE) was established in 2002 to address many of the recommendations of the White Paper. Its brief is to develop and co-ordinate ECCE. Its core objective is to develop a National Framework for Quality (NFQ), that is, a set of quality standards for all of the different settings where early learning takes place, including the infant classes in schools, and a system to evaluate and support compliance with these standards.

In addition to these two key initiatives, the Organisation for Economic Cooperation and Development (OECD) has recently completed a Thematic Review of Early Childhood Education and Care Policy in Ireland (OECD, 2004). It analyses the key policy issues in the early childhood field related to co-ordination, access and quality. In terms of co-ordination, it notes that there is a dispersion of responsibilities regarding ECCE across many ministries including the Department of Health and Children, the Department of Justice, Equality and Law Reform and the Department of Education and Science. It points out that access to accredited developmental programmes for Irish children in the birth to three age range is very weak and that access to early care and education for children in the three to six year age group languishes behind European standards. It expresses a concern about the 'great shortage' of quality services for young children under four years of age and the 'predominantly didactic approach in Early Start and the primary school infant classes' (OECD, 2004, p. 9). It makes a number of recommendations to achieve greater co-ordination, to improve both general access and access for special groups, including children with disabilities and children from disadvantaged backgrounds, and to enhance the quality of services.

\section{Provision and practice}

In terms of provision and practice, progress in relation to a distinct ECCE sector is slower to take shape. There is no overarching funding system for ECCE. State investment is limited, and has actually served to maintain a divide between care and education. Support for childcare comes mainly from the Department of Health and Children through funding for services catering for children at risk and children with special needs. The Department of Justice, Equality and Law Reform funds services through the EOCP, while support for early education is 
provided by the Department of Education and Science through the funding of infant classes in the primary school system.

As of yet, there is no overarching curriculum for ECCE. Hayes (2001) observes that early years services outside the formal school system either provide a particular programme such as Montessori or High/Scope or follow a broad play-based curricular approach. In the schools, the 1971 Primary School Curriculum was superseded by a revised curriculum in 1999, which is child-centred and cherishes the uniqueness of each individual child (DES, 1999b). However, the National Council for Curriculum and Assessment (NCCA, 2004) is currently developing a single framework for early learning to be used by all those working with young children from birth to six years. The development of this framework is a new departure in many ways because it highlights the importance of early learning beginning at birth and addresses it in a more coherent and inclusive manner than heretofore. In so doing, it bridges the artificial divide between care and education.

There is no agreed overarching system for staff qualifications and training in ECCE. Staff working in what is traditionally termed the 'childcare sector' range from having no professional qualifications to having many different qualifications. Attempts are being made to address this variation, notably, the publication of the Model Framework for Education, Training and Professional Development for the Early Childhood Care and Education Sector (DJELR, 2002) provides a co-ordinated vision and clear pathway for training for those working in ECCE services outside the formal school system. In contrast, staff working in what is traditionally known as the "education sector', that is, teachers in the formal school system, have a recognised standardised qualification. However, their pre-service training often offers only a limited focus on the early years. For example, in one College of Education, early childhood studies occupy approximately five per cent of the overall timetable for education. In addition, five per cent of students complete an early childhood elective. While an overarching system for staff qualifications and training in ECCE would require considerable development, it would undoubtedly have benefits, notably, staff specialised to work with children from birth to six years in any setting.

As of yet, there are no all-encompassing regulations or standards for ECCE. Provision within what is traditionally the 'childcare sector' is governed by the Childcare (Pre-school Services) 
Regulations (Department of Health, 1996). Provision in what is traditionally the education sector is governed by the Education Act (DES, 1998) and the Education Welfare Act (DES, 2000), which are relevant to the infant classes in primary schools. The benefits of the aforementioned NFQ by the CECDE include assurance that there is consistency in the quality of provision for children between the ages of birth and six years and again, an integrated approach to care and education.

\section{Research}

The research profile of the ECCE in Ireland has gained momentum. An Audit of Research on Early Childhood Care and Education in Ireland, 1990 - 2003 (CECDE, 2003a) found that, while there was relatively little research prior to 1995 , there was an upsurge from the mid-1990s onwards, covering themes such as children and society, the developing child, early childhood services, quality, parents and families, educational disadvantage and special needs. This reflects the growing availability of early years courses and the fact that ECCE has moved to the forefront of policy and professional debate in recent years. While a growing research profile is apparent, and helps to forge an empirical information base for the development of the ECCE sector, there remains much scope for further progress (CECDE, 2003a, p. 143).

\section{A future perspective}

The analysis of past and present developments in relation to ECCE indicates the substantial progress that has been made in recognising the importance of quality early years experiences which integrate care and education. The emerging ECCE sector and the current developments at policy, practice and research level are promising. However, this emerging sector is very much at an embryonic stage, with significant scope for progress. It is therefore both a critical and opportune time to consider future directions. Our analysis of the evolution of ECCE, coupled with recommendations made in some of the major policy documents, suggests the following key measures:

- ECCE policy needs to be located under the remit of a designated agency. Given the number of government departments that currently play a role in early childhood policy, it would seem expedient to locate it under an agency with links to each ministry. Such an agency would assume responsibility for implementing 
the outstanding recommendations from existing policy documents including the National Childcare Strategy, the White Paper on Early Childhood Education and the OECD report, as well as spearheading the development of an integrated national policy for ECCE.

- There needs to be a substantial increase in State funding to the existing infrastructure of early years settings for children in the birth to six age cohort, focusing particular attention on children aged birth to three. Funding should also be placed under the remit of the designated agency, allocated in a way that (1) encourages greater collaboration and co-operation between early learning centres such as nurseries and crèches and national schools and (2) acts as an incentive to ensure that specified quality standards are met.

- Adequate resources must be made available to facilitate the completion, implementation and evaluation of the NCCA National Framework for Early Learning.

- Staff training, qualifications and ongoing professional development are a matter demanding urgent attention. A clearly articulated framework for the ECCE sector is a necessary prerequisite for ensuring that all those working with young children attain appropriate initial qualifications and engage in regular professional development. This will improve the access, transfer and progression of personnel within the sector. However, developments in relation to standards must be conducted in consultation with stakeholders in ECCE and therefore should take account of the aforementioned Model Framework for Education, Training and Qualifications (DJELR, 2002), which presents a consensual position on these issues.

- The development and implementation of the National Framework for Quality (NFQ) needs to be supported and resourced to maximise its positive impact on the quality of young children's early years experiences.

- There is need for ongoing and enhanced investment in research in ECCE. The aforementioned Research Audit (CECDE, 2003a) revealed a number of gaps in current research. These include aspects such as quality, children's rights, consultation with young children, transition from preschool settings to infant classes, integration of children with special needs, dealing with dispersed incidences of disadvantage and cultural diversity. The CECDE is in the process of implementing a Research Strategy to address these gaps (CECDE, 2003b). A coordinated and concerted research strategy at national level would enhance the empirical 
data to inform future policy and practice relating to ECCE in Ireland.

\section{Conclusion}

Transformations in how we conceptualise childhood are catalysing the emergence of a distinct ECCE sector, which is a relatively new phenomenon in the Irish context. However, much remains to be done in relation to consolidating the identity of this sector. While there has been significant progress in bridging the artificial divide between care and education at policy level, increased elaboration at practice level, supported by Irish research, is required. This would provide assurance that we are responding meaningfully to our youngest children's needs and rights, and providing them with experiences that will enrich their subsequent development and lifelong learning.

\section{REFERENCES}

Arensberg, C. and Kimball, S. (1940) Family and Community in Ireland, Cambridge: Harvard University Press.

Arensberg, C. and Kimball, S. (1968) Family and Community in Ireland: Second Edition, Cambridge: Harvard University Press.

Barnett, W. (2000) Economics of early childhood intervention, in Shonkoff, J. and Meisels, S. (eds) Handbook of Early Childhood Intervention ( $2^{\text {nd }}$ ed.), Cambridge: Cambridge University Press, pp. 589-610.

Central Statistics Office (2002) Census 2002 Volume 3 - Household Composition and Family Units, Dublin: The Stationery Office.

Centre for Early Childhood Development and Education (2003a) An Audit of Research on Early Childhood Care and Education in Ireland 1990-2003, Dublin: Centre for Early Childhood Development and Education.

Centre for Early Childhood Development and Education (2003b) Research Strategy - A Work in Progress, Dublin: Centre for Early Childhood Development and Education.

Clancy, P. (1984) Demographic Changes and the Irish Family: The Changing Family, Dublin: University College.

Cleary, A., Nic Ghiolla Phádraig, M. and Quin, S. (eds) (2001) Understanding Children, Volume 2 - Changing Experiences and Family Forms, Dublin: Oak Tree Press. . 
Committee on Reformatory and Industrial Schools (1970) Reformatory and Industrial School Systems Report, Dublin: The Stationery Office.

Coolahan, J. (1973) A Study of Curricular Policy for the Primary and Secondary Schools of Ireland 1900-1935, with Special Reference to the Irish Language and Irish History, Ph.D Thesis, Dublin: Trinity College Dublin.

Coolahan, J. (1981) Irish Education - History and Structure, Dublin: Institute of Public Administration.

Commissioners of National Education (1901) $67^{\text {th }}$ Report of the Commissioners of National Education in Ireland for 1900, Appendix F, Revised Programme of Instruction in National Schools - Notes, Hints and Observations for the Information of Managers and Teachers, Dublin: Alexander Thom and Co. (Limited).

Currie, J. (2000) Early Childhood Intervention Programs: What do we know?, Washington DC: The Brookings Institution.

Curtin, C. (1986) Marriage and the family, in Clancy, P., Drudy, S., Lynch, K. and O'Dowd, L. (eds) Ireland - A Sociological Profile, Dublin: Institute of Public Administration in Association with The Sociological Association of Ireland, pp. 155-172.

Curtin, C. and Varley, A. (1984) Children and childhood in rural Ireland: a consideration of the ethnographic literature, in Curtin, C., Kelly, M. and O'Dowd, L. (eds) Culture and Ideology in Ireland, Galway: Galway University Press, pp. 3045.

Department of Education (1948) Revised Programme for Infants, Dublin: The Stationery Office.

Department of Education (1971) Primary School Curriculum: Teacher's Handbooks (2 Volumes), Dublin: The Stationery Office.

Department of Education (1990) Report of the Review Body on the - Primary Curriculum, Dublin: The Stationery Office.

Department of Education and Science (1998) Education Act, Dublin: The Stationery Office.

Department of Education and Science (1999a) Ready to Learn - A White Paper on Early Childhood Education, Dublin: The Stationery Office.

Department of Education and Science (1999b) Primary School Curriculum, Dublin: The Stationery Office.

Department of Education and Science (2000) Education Welfare Act, Dublin: The Stationery Office. 
Department of Health (1991) Child Care Act, Dublin: The Stationery Office.

Department of Health (1996) Child Care (Preschool Services) Regulations and Explanatory Guide to Requirements and Procedures for Notification and Inspection, Dublin: The Stationery Office.

Department of Health and Children (1999) Children First - National Guidelines for the Protection and Welfare of Children, Dublin: The Stationery Office.

Department of Health and Children (2000) The National Children's Strategy: Our Children - Their Lives, Dublin: The Stationery Office.

Department of Justice, Equality and Law Reform (1999) National Childcare Strategy, Report of the Partnership 2000 Expert Working Group on Childcare, Dublin: The Stationery Office.

Department of Justice, Equality and Law Reform (2001) The Children Act 2001, Dublin: The Stationery Office.

Department of Justice, Equality and Law Reform (2002) Quality Childcare and Life Long Learning: Model Framework for Education, Training and Professional Development in the Early Childhood Care and Education Sector, Dublin: The Stationery Office.

Department of Social, Community and Family Affairs (1998) Strengthening Families for Life: Final Report of the Commission on the Family to the Minister for Social, Community and Family Affairs, Dublin: The Stationery Office.

Department of Social Welfare (1996) Sharing in Progress. National Anti-Poverty Strategy, Dublin: The Stationery Office.

Douglas, F. (1994) The History of the Irish Pre-Schools Playgroups Association 1969-1994, Dublin: IPPA.

Fahey, T. and McLaughlin, E. (1999) Family and the State, in Heath, A., Breen, R. and Whelan, C. (eds) Ireland North and South Perspectives from Social Science, New York: Oxford University Press, pp. 117-140.

Fox, R. (1978) The Tory Islanders: A People of the Celtic Fringe, New York: Cambridge University Press.

Greene, S. and Moane, G. (2000) Growing up Irish: changing children in a changing society, Irish Journal of Psychology, Vol. 21, No. 3-4, pp. 122-137.

Guralnik, M. (ed.) (1997) The Effectiveness of Early Intervention, Baltimore: P. H. Brookes. 
Hannan, D. and Katsiaouni, L. (1977) Traditional Families? From Culturally Prescribed to Negotiated Roles in Farm Families, Dublin: The Economic and Social Research Institute.

Harvey, B. (2001) Report re Socio-Economic Environment, Dublin: Barnardos' National Children's Resource Centre.

Hayes, N. (2001) Early childhood education in Ireland: policy, provision and practice, Administration, Vol. 49, No. 3, pp. 4367.

Holahan, A. and Costenbader, V. (2000) A comparison of developmental gains for preschool children with disabilities in inclusive and self-contained classrooms, Topics in Early Childhood Special Education, Vol. 20, No. 4, pp. 224-235.

Humphreys, A. (1966) New Dubliners - Urbanisation and the Irish Family, London: Routledge and Kegan Paul.

Hyland, A. (1987) The process of curriculum change in the Irish national school system, Irish Educational Studies, Vol. 6, No. 2, pp. 17-38.

Kennedy, F. (1989) Family, Economy and Government in Ireland, Dublin: The Economic and Social Research Institute.

Kerrigan, G. (1998) Another Country: Growing up in 1950s Ireland, Dublin: Gill and MacMillan.

Lalor, K. (ed.) (2000) The End of Innocence: Child Sexual Abuse in Ireland, Dublin: Oak Tree Press.

National Council for Curriculum and Assessment (2004) Towards a Framework for Early Learning - A Consultative Document, Dublin: NCCA.

National Programme Conference (1922) National Programme of Primary Instruction, Dublin: The Educational Company of Ireland.

O'Connor, M. (1987) Infant education in independent Ireland 19221971, An Múinteoir, Vol. 2, No. 1, pp. 5-7.

O'Sullivan, E. and Raftery, M. (1999) Suffer the Little Children: The Inside Story of Ireland's Industrial Schools, Dublin: New Island.

Organisation for Economic Co-operation and Development (2004) OECD Thematic Review of Early Childhood Education and Care Policy in Ireland (including Background Report Ireland), Dublin: The Stationery Office.

Peskett, C. and Roberts, H. (1972) A pilot study of child-rearing practices among mothers of young children in Dublin, Economic and Social Review, Vol. 3, No. 4, pp. 277-294. 
Scheper-Hughes, N. (1979) Saints, Scholars, and Schizophrenics Mental Illness in Rural Ireland, Los Angeles: University of California Press.

Shonkoff, J. and Meisels, S. (eds) (2000) Handbook of Early Childhood Intervention ( $2^{\text {nd }}$ ed.), Cambridge: Cambridge University Press.

Smyth, M. (2003) The concept of childhood and the experience of children in violently divided societies, in Dunne, J. and Kelly, J. (eds) Childhood and its Discontents - The First Seamus Heaney Lectures, Dublin: The Liffey Press, pp. 159-198.

Starkie, W. (1911) The History of Irish Primary and Secondary Education During the Last Decade - An Inaugural Address, Belfast.

Sylva, K. (2002) The role of research in explaining the past and shaping the future, in Abbott, L. and Moylett, H. (eds) Early Education Transformed, London: Routledge Falmer.

United Nations (1989) The Convention on the Right of the Child, New York: United Nations.

Warfield, M.E. (1994) A cost effectiveness analysis of early intervention services in Massachusetts: implications for policy, Educational Evaluation and Policy Analysis, Vol. 16, No. 1, pp. 87-99. 